\title{
R\&D DRIVERS AND OBSTACLES TO INNOVATION IN THE ENERGY INDUSTRY
}

Costa-Campi, M.T., Department of Public Economics, Chair on Energy and Environmental Sustainability and Barcelona Institute of Economics, University of Barcelona. E-mail: mtcosta@ub.edu

Duch-Brown, N., Institute for Prospective Technological Studies, European Commission; Department of Public Economics, Chair on Energy and Environmental Sustainability and Barcelona Institute of Economics, University of Barcelona. E-mail: nduch@ub.edu

García-Quevedo, J., Department of Public Economics, Chair on Energy and Environmental Sustainability and Barcelona Institute of Economics, University of Barcelona. E-mail: jgarciaq@ub.edu

\begin{abstract}
The energy industry is facing substantial challenges that require the fostering of innovation. In this paper we analyse the main drivers of $R \& D$ investment and obstacles to innovation in this industry. We examine, firstly, whether the stated R\&D objectives pursued by firms play a role in their R\&D effort. Secondly, we analyse the effects of financial, knowledge and market barriers on the innovation outcomes of the firms. The data is taken from the Technological Innovation Panel (PITEC) for Spanish firms for the period 2004-2010. We use a structural model with three equations corresponding to the decision to carry out $\mathrm{R} \& \mathrm{D}$ or not, the $\mathrm{R} \& \mathrm{D}$ effort, and the production of innovations. The results of the econometric estimations show, first, that R\&D intensity is positively related to process innovation. Second, the main barriers that hamper innovation in the energy industry are related to market factors while financial and knowledge obstacles are not significant.
\end{abstract}

Keywords: R\&D, innovation, energy, barriers, regulation

JEL Classification: Q40, O31 


\section{INTRODUCTION}

The energy sector is facing major challenges in most of its activities and segments. The main challenges are related to the mitigation of climate change, to increasing efficiency and to guaranteeing energy security. Many recent reports and papers (Anadon et al. 2011; Nakicenovic and Nordhaus, 2011; OECD, 2011; Anadon, 2012; IEA, 2012) have stressed that fostering innovation is crucial to meeting these challenges. Nevertheless, the level of R\&D investment and innovation in the energy industry remains quite low (GEA, 2012).

Many papers have analysed the determinants of $R \& D$ and the barriers that firms face in the manufacturing sector (Griffith et al., 2006; Savignac, 2008; Cohen, 2010). In addition some recent papers have examined the effects of the liberalisation and restructuring of the electricity markets on R\&D investments (Jamasb and Pollit, 2008; Sanyal and Cohen, 2009; Salies, 2010; Kim et al., 2012).

The lack of data on R\&D activities in the energy industry has made the determinants of $\mathrm{R} \& \mathrm{D}$ and innovative behaviour in this sector difficult to analyse (Jamasb and Pollit, 2008; European Commission, 2009a; Anadon et al., 2011; Gallagher et al., 2012). Therefore very few papers have examined R\&D drivers for the energy industry (Salies, 2010; Kim et al., 2012; Sterlacchini, 2012) and, to our knowledge, the effect of the whole set of obstacles to innovation in the energy industry has not been empirically analysed.

The main objective of this paper is to analyse the forces that drive $R \& D$ and the barriers that firms face in innovating in the energy industry. First, the analysis distinguishes between, on the one hand, those factors influencing the decision about whether to do R\&D or not, and on the other, those that affect the relative amount of resources devoted to $R \& D$. Second, the effects of financial barriers and other potential obstacles to innovation connected with knowledge and market factors are examined. In particular, we analyse whether the existence of dominant incumbents is affecting innovation.

The empirical analysis is carried out using information provided by the Spanish Technological Innovation Panel (PITEC) for the period from 2004 to 2010. This period 
is characterised by a competitive situation after the main changes in the regulation of the energy industry and the liberalisation process it underwent in the late nineties. In addition, in this period, all the energy firms in Spain were privately-owned. The law liberalising the electricity sector was passed in 1997 and there have been no state-owned energy firms in Spain since 1998.

The identification of the $R \& D$ drivers and the factors that hamper innovation in the energy industry has significant policy implications that are important for the design of adequate instruments that can incentivize $R \& D$ investment in this sector.

After this introduction, the paper is organized as follows. The next section provides a brief discussion of the main characteristics of $R \& D$ and innovation activities in the energy industry and reviews the empirical literature. The third section describes the database, presents the specification of the model and explains the variables used. The fourth section presents the econometric estimation and discusses the estimation results. The paper ends with a concluding section.

\section{R\&D AND INNOVATION IN THE ENERGY INDUSTRY}

The empirical literature on $R \& D$ and innovation in the energy industry has been fundamentally oriented towards explaining how the liberalisation process has influenced R\&D projects (Dooley, 1998; Markard and Truffer, 2006; Jamasb and Pollit, 2008; Sanyal and Cohen, 2009; Salies, 2010; Kim et al., 2012; Sterlacchini, 2012; Sanyal and Ghosh, 2013). The empirical study of the drivers, and more specifically the obstacles to investment in $R \& D$ and innovation in a market situation, has received less attention and there are fewer studies (Salies, 2010; Kim et al., 2012; Sterlacchini, 2012).

Among drivers, the empirical studies on economics of innovation (Cohen, 2010) have extensively analysed the effects of the size of firms and shown that it is a barrier to entry for deciding whether to invest in R\&D. In the energy sector this barrier is more evident because the structure of the market is still highly concentrated. This can be explained by the high fixed costs of nuclear, thermal and large-scale hydro-electric technologies, even though a sustained reduction in the indices of concentration in the 
generation market can be seen with the entrance of generating plants for renewable energy and an increase in competition in the retail market with the entrance of new suppliers. The literature shows that the size of the energy companies affects taking a decision to invest in $R \& D$ and the objective of the project. The empirical studies conclude that size positively influences the decision to perform R\&D (Sanyal, 2007; Jamasb and Pollit, 2008; Sanyal and Cohen, 2009; Salies, 2010; Salies and Nesta, 2010; Kim et al., 2012).

The main barriers considered in the literature on economics of innovation are cost, knowledge and market factors. The first of these, financial constraints, is related to characteristics of innovation projects such as the high degree of uncertainty or the existence of information asymmetries. These market failures may explain the existence of financial barriers and particularly difficulties in obtaining external funding (Hall, 2002). Other factors, more related with a systemic view of innovation, such as the lack of qualified personnel, or a market dominated by established enterprises, may also hamper innovation activity (OECD, 2005; D'Este et al., 2012; Blanchard et al., 2013). The specific characteristics of $R \& D$ activities in the energy industry such as the large scale of the projects or incumbent inertia with the dominance of existing technologies (Anadon et al., 2011; OECD, 2011) may explain the influence of specific factors on the decision to innovate or on the expected results of innovation activities.

The empirical analyses of $\mathrm{R} \& \mathrm{D}$ and innovation in the energy industry have mainly analysed the costs barriers. The empirical results show that firms are not financially constrained as their access to liquidity does not intervene in their R\&D and innovation investment decisions (Salies, 2010). Jalivand and Kim (2012) observe that investment in innovation and R\&D is not considered by utilities to be a strategic investment, and was not even before the liberalisation process, in contrast to companies in the technology intensive sector. On the other hand there is a notable extensive commitment to capital expenditures investment. Slack resources have been invested in specific assets generation technologies and network - in improvements in the efficiency of operating technologies and in increases in productivity. From the results obtained it can be inferred that there is a trade-off between investment in specific assets and investment in $R \& D$ and that firms evaluate the opportunity cost of investment in R\&D. In spite of the financial tension that can be found in the work of Jalivand and Kim (2012), recent 
studies do not obtain significant results when attempting to explain the possible effects of financial constraints on R\&D (Salies, 2010; Sterlacchini, 2012).

The technological mix of energy generation influences R\&D and innovation (Markard and Truffer, 2006; Salies, 2010; Anadon, 2012; Sterlacchini, 2012). The entry of new agents with low carbon emission technologies has meant a change in the composition and the dimension of $R \& D$. The prevalent technology, widely dominated by the incumbent firms, can encourage or impede innovative projects in alternative technologies. In the case of hydro-electric energy it is shown that it appears to be associated with innovation and $\mathrm{R} \& \mathrm{D}$ in renewable energy while nuclear and fossil energies act as a barrier to the entry of radical innovations in renewable energies (Markard and Truffer, 2006; Salies, 2010). In other words, the technological mix is a barrier to entry when the incumbent firms concentrate their portfolio in nuclear and fossil energies. Faced with this, energy policy focused on the fostering of renewable energies implements support mechanisms designed to compensate for production costs in a precompetitive phase. This policy has an asymetric effect on R\&D and innovation, encouraging projects related to new technologies as opposed to projects in the fossil and nuclear energy source sectors. (Salies and Nesta, 2010). These sectors concentrate their $R \& D$ on the development and registration of patents for $R \& D$ projects carried out in previous periods and they focus on applications and on the introduction of innovations in their existing assets (Jamasb and Pollit, 2008; Salies and Nesta, 2010).

The literature distinguishes between two types of objective and $R \& D$ and innovation project. The first type, most frequently carried out by firms, is targeted at immediate applications and short-term returns. These projects seek to improve the efficiency of the industrial process through incremental innovation or to enable innovative technological complementarities that in turn may demand new organisational strategies and the expansion of markets. R\&D in smart grids, smart metering and wind and solar energies brings efficiency, greater profitability and short-term competitive reinforcement. R\&D in capturing carbon dioxide emitted by thermal power plants also shows the same characteristics as it reinforces the competitiveness of a conventional technology. Salies (2010) also includes hybrid or electric vehicles in this type of R\&D. These innovations are incremental and their effectiveness is measured in terms of improvements in profits within a foreseeable period. In competitive conditions, utilities orient their R\&D 
projects towards the objective of consolidating their competitive position in relation to rival firms (Defeuilly and Furtado, 2000).

In comparison to these projects, other $\mathrm{R} \& \mathrm{D}$ projects require long periods of research and they contribute to potentially disruptive innovations directly focused on climate change mitigation such as fuel cell batteries, tidal turbine systems, storage, and biomass gasification (Salies, 2010). Some of these projects require large amounts of resources, scientific knowledge, the transmission of information between the different phases of the industrial process and are of a non-commercial nature, even as precompetitive technology. They require public policy for their implementation and public-private partnerships for their development (Newell, 2010; Henderson and Newell, 2011). Hence, in a competitive energy market, public support is crucial for R\&D and innovation projects focused on climate change mitigation given that they have no possibility of being carried out privately. Meeting the challenge of climate change mitigation is not incompatible with the encouragement of competition and innovation in the utilities and a systemic focus for $R \& D$ is required so that public investment in $R \& D$ draws private investment to the utilities and to end-user technologies (Gallagher at al., 2012).

\section{DATA AND MODEL SPECIFICATION}

The empirical analysis was carried out using the Spanish Technological Innovation Panel (PITEC) for the period from 2004 to 2010. PITEC is the result of collaboration between the Spanish National Statistics Institute and the COTEC foundation aimed at providing data from the Community Innovation Survey (CIS), which is carried out annually following the guidelines of the OECD's Oslo Manual. The PITEC offers comprehensive and detailed information on the characteristics of Spanish firms and their innovative activities. While the CIS dataset offers a cross section, the Spanish PITEC overcomes this drawback by providing panel data. The dataset provides exhaustive information for more than 12,000 firms for the period 2004-2010 and has been frequently used to carry out empirical analyses on innovation (Barge-Gil, 2010; De Marchi, 2012). 
Given the structure of the PITEC dataset, our definition of the energy industry includes all activities related with the generation, transmission, distribution and retailing of energy. PITEC, like the CIS statistics for other European countries, provides a lot of aggregated sectoral data. In particular, the data for two divisions of the NACE, namely electricity, gas, steam and air conditioning supply (NACE Rev. 2, 35) and Water collection, treatment and supply (NACE 36) are aggregated into one sector (energy and water). Fortunately, in Spain, all the gas and electricity companies have been privately owned since 1998, whereas almost all water companies are state-owned. Hence, using a variable for ownership, we were able to remove the state-owned firms from the sample of utilities included in PITEC that we believe are in NACE sector 36 (water). In this way we are able to restrict the analysis to the activities included in NACE 35 (energy). Unfortunately, however, we are not able to identify firms more precisely.

In addition to this filtering process, we excluded firms that meet the three following conditions: they have not innovated, they do not perceive any obstacle to innovation and state that they do no need to innovate. With this procedure we follow that of recent literature on barriers and innovation and we only consider firms that are potential innovators, correcting for the potential sample selection bias intrinsic to this type of analysis (Savignac, 2008; D’Este et al., 2012; Blanchard et al., 2013, Pellegrino and Savona, 2013).

After filtering out these firms, 410 observations are available for energy companies forming an unbalanced panel for the period 2004-2010. Although PITEC also provides information for the year 2003, these data are incomplete and, in particular, there is no information for the year 2003 on obstacles to innovation. Nevertheless, in the estimations where we use a lag of an independent variable, we have also used the data for 2003 to avoid information loss.

As explained above, the sample includes the gas and electricity firms in all the phases of the industrial process. Since no deeper sectoral disaggregation is available, and because of confidentiality requirements, it is not possible to include any further distinction between the firms. In addition, it would have been interesting to include other industries in the analysis of R\&D in the energy sector such as, for example, the manufacture of electrical equipment (NACE 27). Nevertheless, as for other energy demand industries, 
there is no information available to differentiate their R\&D and innovation into energy and non-energy related companies (GEA, 2012, page 1680).

The main characteristics of the firms in the Spanish energy industry (see Table 1 for descriptive statistics) show that they are on average quite big, with a mean size of more than 600 employees. More than half the energy companies (59.1\%) reported performing $R \& D$ activities and the mean $R \& D$ effort ( $R \& D$ expenditure as a percentage of sales) is 1.7\%. Although process innovation is much more frequent (65.6\%) a substantial proportion of firms $(39 \%)$ has also introduced product innovations. These data are consistent with recent reports on innovation in the energy industry in Spain (Molero, 2012; Economics for Energy, 2013) showing that R\&D and innovation levels are, similarly to those observed in other European countries, low for the size and importance of this sector in the Spanish economy.

\section{TABLE 1}

The Spanish energy industry has undergone a similar transformation to that in other European countries. Liberalisation has involved an increase in the number of firms and a reduction in the concentration of the market. When comparing the wholesale market position of European countries, Spain is close to the average in terms of the number of companies with more than a $5 \%$ share of generation capacity and the share of the three biggest companies. This is also the case when analysing structural business indicators such as the firms' turnover and gross added value per employee or the proportion of personnel costs in production costs $(\%)$ or the investment rates (European Commission, 2009b). In addition, the Spanish electric and gas regulations are totally harmonised with the European norm. The process of liberalisation and the transposition of European energy directives ${ }^{1}$ started only one year after the European Directive for the

\footnotetext{
${ }^{1}$ European Union directives lay down certain end results that must be achieved by every Member State. National authorities have to adapt their laws (commonly referred to as transposition) to meet these goals, but are free to decide how to do so. Directives may concern one or more Member States, or all of them. Each directive specifies the date by which the national laws must be adapted - giving national authorities room for manoeuvre within the deadlines necessary to take account of differing national situations. If a member state fails to pass the required national legislation, or if the national legislation does not adequately comply with the requirements of the directive, the European Commission may initiate legal action against the member state in the European Court of Justice (See http://ec.europa.eu/eu_law/).
} 
liberalisation of the European Energy sector was approved (Directive 96/92/CE). The liberalisation of the Spanish electricity sector is based on Law 55/1997 and for the gas sector on Law 34/1998. Today, all the transpositions have been completed, and this process has been accompanied by the corresponding modification of domestic laws. Unbundling imposes the absolute separation of ownership of the TSO (Transmission System Operator) from the rest of the operators, enforces TPA (third party access) to networks, and establishes competition criteria between all the participants (with separation of activities) both in wholesale and retail markets. The liberalisation process has reduced concentration in the sector to levels below the EU-27 average and only the transport and distribution networks maintain regulated returns, as the European norm establishes.

The model used for the estimation of the determinants of investment in R\&D by energy companies is based on the structural model proposed by Crepon et al. (1998). This model, known as CDM, has been used in numerous empirical analyses (see, among others, Griffith et al., 2006, Hall et al., 2009; 2013). The literature on the economics of innovation and on industrial organisation has emphasized that there are considerable differences in innovative activity between industries and the importance of studying innovation determinants for specific sectors (Becheikh et al., 2006; Cohen, 2010). Together with the studies that specifically analyse R\&D in the energy industry (Sanyal and Cohen, 2009; Salies, 2010; Kim et al., 2012), other papers have analysed R\&D in other specific industries (see, among others, Cumming and Macintosh, 2000) and, when possible, have carried out the estimations separately for each industry (Doraszelski and Jaumandreu, 2013). In addition, with the use of a CDM framework, some analyses (Segarra, 2010) have emphasized the heterogeneity between sectors and carried out the estimations separately for manufactures and services and by discriminating according to the level of technology.

In this paper, we use the CDM framework to analyse $R \& D$ and innovation determinants specifically in the energy industry. We use the first three equations that model business decisions relating to $R \& D$ and the innovations produced as a result of this investment. The first equation concerns the firm's dichotomous decision to spend on R\&D or not 
while the second corresponds to the intensity of the total $R \& D$ effort or $R \& D$ investment function. Finally, the third equation corresponds to the innovation function. This equation consists of a set of binary innovation outcomes. We consider total innovation but we also separately specify one equation for product innovation and another for process innovation as in Griffitth et al. (2006) and Hall et al. (2009). Formally:

$$
\begin{gathered}
D_{i t}=\left\{\begin{array}{l}
1 \text { if } \delta Z_{i t}+\varphi_{i}+\varepsilon_{1 i t}>0 \\
0 \text { if } \delta Z_{i t}+\varphi_{i}+\varepsilon_{1 i t}<0
\end{array}\right. \\
R \& D_{i t}=\left\{\begin{array}{c}
\beta X_{i t}+\alpha_{i}+\varepsilon_{2 i t} \text { if } D_{i t}=1 \\
0 \text { if } D_{i t}=0
\end{array}\right. \\
I N N_{i t}=\gamma R \& D^{*}{ }_{i t}+\beta W_{i t}+\mu_{i t}
\end{gathered}
$$

Equations (1) and (2), that are estimated jointly, model the decision to spend on R\&D or not and the R\&D effort according to a set of explanatory variables $-\left(Z_{i t}\right)$ and $\left(X_{i t}\right)$ respectively- which are detailed below. Previous empirical analyses modelling R\&D spending in utilities have also considered research expenditure decisions to be a twostep process (Sanyal and Cohen, 2009). Although there is no general consensus in the literature on how to measure either decision it is considered that the selection equation (1) is a strategic one, longer term, to be or not an innovative company, while the second (2) is more focused on the short term, on setting annual or multi-annual budgets to be spent on R\&D (Artés, 2009). The innovation equation (3) is specified in terms of the latent R\&D intensity as in the original CDM model and subsequent works (Griffitth et al. 2006; Hall et al. 2009; 2013). In this equation, other firm characteristics that affect product and process innovation are also included.

In the selection equation (1), $D_{\text {it }}$ takes the value 1 if the firm has or reports positive R\&D expenditures. Nevertheless, as Salies (2010) points out, when a firm does not report $R \& D$ expenditures it is difficult to know what these zeros represent, whether an endogenous decision or a randomly missing process. Although it is necessary to be cautious, we consider, like Sanyal and Cohen (2009), that they represent decisions not to perform any $R \& D$. In our panel data, $R \& D$ exhibits a high degree of persistence and 
changes of status from performing $R \& D$ to not performing or vice-versa are almost always permanent.

In both equations (1) and (2) size, age and public funds are explanatory variables. First, firm size is a key variable in any analysis of the determinants of investment in R\&D or innovation in general (Cohen, 2010). The expected sign of this variable is positive, since according to the literature for the sector, larger companies are most likely to invest in R\&D (Jamasb and Pollitt, 2008; Sanyal and Cohen, 2009; Salies, 2010), despite the competitive pressures that market liberalisation has introduced and that would largely relax the Shumpeterian hypotheses. Second, including age in the models of determinants of $R \& D$ is relatively recent, although the literature has emphasized the importance of new entrants for innovation and economic growth (Baumol et al., 2007). The reason for its omission was the lack of information about age in innovation surveys, which however PITEC does offer.

Third, numerous studies have examined the effects of subsidies on the R\&D decisions of firms and, in particular, on the possible additionality of public support to private R\&D (David et al., 2000). Some papers (Callejón and García-Quevedo, 2005) show that the sectoral reaction to $R \& D$ subsidies is not uniform and that while in some cases a significant additional effect occurs, in others the effect is very limited. The variable public funds is included in both equations according to the framework proposed by Griffith et al. (2006) and in the same way as recent papers using the CDM approach (Hall et al., 2009; 2013). Nevertheless this variable presents endogeneity problems, particularly when it is included in the selection equation, because obtaining public support is related with prior $\mathrm{R} \& \mathrm{D}$ and innovation performance. To avoid, at least partially, these problems we have carried out the estimation with a lag of the variable public funds in this equation, following a common procedure in the literature (see, among others, García-Quevedo et al., 2014). In addition, as explained in the robustness section, we have also carried out the estimation dropping this variable out for the selection equation.

In the intensity equation (2), we have also considered foreign capital, cooperation with other firms and institutions and particularly the variables related to the objectives of innovation. Firms may engage in innovation and devote resources to R\&D for a number 
of different reasons. With the inclusion of these variables we are able to examine the relationship between the different forces that drive innovation activity and $R \& D$ intensity.

In Technological Innovation Surveys and also in the Spanish version of the CIS, innovative firms are asked to report the relevance and the degree of importance of innovation objectives. Specifically, objectives oriented to product innovation (expansion of the range of goods and services, greater market share) and to process innovation (to increase production capacity, reduction of costs per unit of output) are considered. There are also other innovation objectives considered in the survey that may become relevant in the energy sector. These are $R \& D$ projects aimed at reducing the environmental impact of the activity and also $R \& D$ projects designed to meet environmental, health and safety regulations. In the estimation of equation (2) each of these objectives is measured by a dummy variable indicating whether the firm considers each specific factor to be of high importance.

In the third equation we consider total innovation, process or product, but we also distinguish, as pointed out above, between the two different innovation outcomes. In all three cases, the innovation outcome is measured with a dummy variable ${ }^{2}$. In these estimations we include the potential obstacles to innovation in the vector of explanatory variables $\left(\mathrm{W}_{\mathrm{it}}\right)$ with the purpose of examining what type of barriers that may hamper innovation are relevant for the energy industry.

We control also for the size of the firms and we consider whether the firms belong to a group because this may help them to overcome financial barriers more easily in comparison to an independent firm. In addition we include, similarly to Griffitth et al. (2006), Hall et al. (2009; 2013), the predicted value for R\&D effort estimated from equation (2) that proxy the latent $R \& D$ intensity. By using this value $\left(R \& D *_{i t}\right)$, as explained later, we instrument the R\&D effort and take care of possible endogeneity problems. Although in the innovation equation we distinguish between product and process innovation, we use the same $R \& D$ values for both equations. The PITEC

\footnotetext{
${ }^{2}$ The Community Innovation Survey only asks the firms whether they have introduced a new or significantly improved good or service or implemented a new or significantly improved production process, distribution method or supporting activity, but not the number of product or process innovations.
} 
database, as is common in the different Community Innovation Surveys, does not separate $\mathrm{R} \& \mathrm{D}$ expenditures according to their orientation towards product or process innovation.

All the firms, innovative or not, are asked in the Spanish Innovation Survey, as in most technological innovation surveys, to report the relevance and the degree of importance of some specific factors that have hampered innovation activities or influenced a decision not to innovate (OECD, 2005). In the estimations we have considered the following factors: cost, knowledge, market dominated by established firms and uncertain demand ${ }^{3}$. Each of these barriers is measured by a dummy variable indicating whether the firm considers the specific factor to be of high importance.

In addition to the explanatory variables, in the equations we take into account timeinvariant and unobservable specific firm characteristics and time effects in order to control for possible shocks arising from changes in the volatile economic cycle covered in the analysis as well as regulatory changes that have occurred in the sector that may have had an effect on the R\&D and innovation behaviour of energy companies.

\section{ESTIMATION, RESULTS AND DISCUSSION}

Most of the empirical work on the estimation of the impact of innovation on productivity has relied on the CDM model explained schematically in the previous section. This model is essentially a recursive system in which a first block explains both the probability of doing $R \& D$ and the intensity of the $R \& D$ undertaken; and a second block analyses the probability of being innovative, and the extent of product and/or

\footnotetext{
3 Another factor considered in the literature, that may constrain innovation activities is government regulations. In some countries, like the United Kingdom, this information is in the CIS questionnaire. Spain uses, for the section on factors hampering innovation, the harmonised CIS survey questionnaire, and like other countries (e.g., France, Germany and Italy) the factors related to national or European regulation are not in the questionnaire. In consequence this information is not available in PITEC. Although it would have been interesting to include regulation factors in the estimations, it does not seem to have been for the period of analysis a barrier of great importance for Spanish firms. A report for Spain (Economics for Energy, 2013) that analyses innovation in the energy sector does not include regulation among the main factors or barriers hampering innovation.
} 
process innovation. Finally, a third block (not estimated in this paper), uses innovation output and other explanatory variables to estimate a productivity equation.

Generally, the model is static and unidirectional (productivity does not affect R\&D or innovation) and it is estimated using cross-section data. These characteristics reflect the limitations of the innovation surveys in the majority of countries, where a new sample is drawn for each wave, hindering the possibility of any panel data analysis. This model deals with the endogeneity of $R \& D$ in the innovation equation and the possible selection bias of the R\&D performers. In the original model, all equations were estimated jointly by asymptotic least squares, but most subsequent studies have relied on a sequential estimation procedure, where the predicted value of the endogenous variable in the outcome equation enters as an explanatory variable in the following block (equation 3 ). In this respect, Musolesi and Huiban (2010) show that differences in the results derived from sequential instrumental variable estimation and maximum likelihood estimation are not important. Hence, the results are rather more robust in the estimation method if endogeneity and selection bias are taken into account (Mohnen and Hall, 2013).

However, as explained in the previous section, we do have a panel of firms. In this case, efficiency gains in the estimation are expected since it is possible to take into account differences between firms that may be related to variables not included in the empirical model. Generally speaking, not controlling for these frequently unobserved factors can lead to biased estimates. A standard solution to this problem is the estimation of fixed or random effects models for panel data, and this is the approach we use in the estimation.

The main challenge in estimating the CDM model arises from the characteristics of the first block, mainly due to the possible selection bias of $R \& D$ performers. Until very recently, the estimation of sample selection models with panel data was restricted to static or partially dynamic frameworks or relied on semiparametric estimators (Arellano and Honoré, 2001; Gayle and Viauroux, 2007). However, Raymond et al. (2007; 2010) have proposed a full parametric random-effects dynamic panel data sample selection estimator in order to overcome the main difficulties that arise in such a setting, namely the presence of unobserved individual effects and the treatment of initial conditions. Unfortunately, the small sample of energy firms included in the PITEC and used in this paper prevents a full dynamic consideration of the model. In a static framework, the 
initial conditions problem is not an issue and we will not tackle it here. Fortunately, the model is flexible enough to contain several different specifications (with or without dynamics or sample selection), yet allows for a more efficient joint estimation of parameters.

\subsection{Estimation procedure}

In order to estimate the first block of the CDM model efficiently the proposed econometric procedure was estimated by Maximum Likelihood thus overcoming the two main difficulties referred previously, the presence of individual effects and the consideration of the initial conditions in a dynamic setting. The method proposes the use of random effects, since fixed effects in this case are subject to many shortcomings, especially when the panel consists of a large number of individuals (firms) and a small number of time observations. For instance, a conditional maximum likelihood estimator could be used to solve the inconsistency problem inherent in estimating a potentially large number of dummy variables for individual effects by maximum likelihood when the number of periods is small. However, this is restrictive in the sense that it is normally not possible to concentrate the likelihood with regard to the individual effects. Moreover, even if it were possible, it would work only under the assumption of the strict exogeneity of the explanatory variables, ruling out the use of lagged dependent variables as explanatory variables (Neyman and Scott, 1948).

More specifically, the first block of the CDM model outlined in the previous section consists of equations (1) and (2). Equation (1) is the selection equation that determines whether individual $i$ is included in the sample on which the estimation of the equation of interest (equation 2) is based, in period t. It is a function of strictly exogenous explanatory variables $\left(\boldsymbol{Z}_{i t}\right)$, time-invariant unobserved individual effects $\left(\varphi_{i}\right)$, and other time-variant unobserved variables $\left(\epsilon_{1 i t}\right)$. The vector $\delta^{\prime}$ captures the effects of the explanatory variables on the current selection process, and is to be estimated. The equation of interest depends on strictly exogenous explanatory variables $\left(\boldsymbol{X}_{i t}\right)$, timeinvariant unobserved individual effects $\left(\alpha_{i}\right)$, and other time-variant unobserved variables $\left(\epsilon_{2 i t}\right)$, and is observed only when $D_{i t}$ is positive. The vector $\beta^{\prime}$ captures the effects of explanatory variables on current outcome, and is to be estimated as well. In this case, since a fully parametric approach has been designed for the estimation of this 
first block of the CDM model, there is no need for exclusion restrictions in the vector of strictly exogenous explanatory variables, making it possible that $\boldsymbol{Z}_{i t}$ and $\boldsymbol{X}_{i t}$ are the same, totally different or that they have common explanatory variables.

For the purpose of estimation, the individual effects are assumed, in every period, to be linear with regard to the strictly exogenous explanatory variables:

$$
\begin{gathered}
\varphi_{i}=b_{0}^{S}+b_{1}^{S} D_{i 0}+\mathbf{b}_{2}^{\prime s} \boldsymbol{Z}_{i}+a_{1 i} \\
\alpha_{i}=b_{0}^{r}+b_{1}^{r} R \& D_{i 0}+\mathbf{b}_{2}^{\prime r} \boldsymbol{X}_{i}+a_{2 i}
\end{gathered}
$$

where $\boldsymbol{Z}_{i}^{\prime}=\left(\boldsymbol{Z}_{i 1}^{\prime}, \ldots, \boldsymbol{Z}_{i T}^{\prime}\right), \boldsymbol{X}_{i}^{\prime}=\left(\boldsymbol{X}_{i 1}^{\prime}, \ldots, \boldsymbol{X}_{i T}^{\prime}\right), b_{0}^{s}, b_{1}^{s}, \mathbf{b}_{2}^{\prime s}, b_{0}^{r}, b_{1}^{r}, \quad \mathbf{b}_{2}^{\prime r}$ are to be estimated, and $a_{1 i}$ and $a_{2 i}$ are independent of $\left(D_{i 0}, \boldsymbol{Z}_{i}\right)$ and $\left(R \& D_{i 0}, \boldsymbol{X}_{i}\right)$ respectively. The scalars $b_{1}^{s}$ and $b_{1}^{r}$ capture the dependence of the individual effects on the initial conditions. The vectors $\left(\epsilon_{1 i t}, \epsilon_{2 i t}\right)^{\prime}$ and $\left(a_{1 i}, a_{2 i}\right)^{\prime}$ are assumed to be independent of each other, and independently and identically distributed over time and across individuals following a normal distribution with mean zero and covariance matrices

$$
\Omega_{\epsilon_{1} \epsilon_{2}}=\left(\begin{array}{cc}
\sigma_{\epsilon_{1}}^{2} & \rho_{\epsilon_{1} \epsilon_{2}} \sigma_{\epsilon_{1}} \sigma_{\epsilon_{2}} \\
\rho_{\epsilon_{1} \epsilon_{2}} \sigma_{\epsilon_{1}} \sigma_{\epsilon_{2}} & \sigma_{\epsilon_{2}}^{2}
\end{array}\right) \quad \text { and } \quad \Omega_{a_{1} a_{2}}=\left(\begin{array}{cc}
\sigma_{a_{1}}^{2} & \rho_{a_{1} a_{2}} \sigma_{a_{1}} \sigma_{a_{2}} \\
\rho_{a_{1} a_{2}} \sigma_{a_{1}} \sigma_{a_{2}} & \sigma_{a_{2}}^{2}
\end{array}\right)
$$

respectively. The parameters of the covariance matrices are also to be estimated. Hence, the likelihood function of individual $i$, starting from $t=1$ and conditional on the regressors and the initial conditions, is written as

$$
L_{i}=\iint_{-\infty}^{\infty} \prod_{t=1}^{T} L_{i t}\left(D_{i t}, R \& D_{i t} \mid D_{i 0}, \boldsymbol{Z}_{i}, R \& D_{i 0}, \boldsymbol{X}_{i}, a_{1 i}, a_{2 i}\right) g\left(a_{1 i}, a_{2 i}\right) d a_{1 i} d a_{2 i}
$$

where $\prod_{t=1}^{T} L_{i t}\left(D_{i t}, R \& D_{i t} \mid D_{i 0}, \boldsymbol{Z}_{i}, R \& D_{i 0}, \boldsymbol{X}_{i}, a_{1 i}, a_{2 i}\right)$ and $g\left(a_{1 i}, a_{2 i}\right)$ denote the likelihood function of individual $i$ conditional on the individual effects, and the bivariate normal density function of $\left(a_{1 i}, a_{2 i}\right)$ respectively. With some transformations (please refer to Raymond et al., 2007 for details), the double integral in equation (4) can be approximated by a "two-step" Gauss-Hermite quadrature so that the random effects individual likelihood function of the model becomes a function of the weights and abscissas of the first and second step of the numerical approximation of the likelihood function. Hence, the product over $i$ of the resultant approximate likelihood function can 
be maximised using standard numerical procedures to obtain the desired estimates of the parameters of the model (see Raymond et al. 2007 and 2010 for technical details about the procedure).

To summarize, the proposed model assumes that the individual effects are, in every period, linear with regard to the strictly exogenous explanatory variables. Hence, the likelihood function of a given individual starting at the initial period and conditional on the regressors is a function of the likelihood function of that individual conditional on the individual effects and a bivariate normal density function of cross-equation individual effects. Hence, the individual effects are "integrated-out" with respect to their joint normal distribution. The resulting likelihood function covers a wide range of likelihood functions of panel data models the estimation of which can be done by simply making restriction assumptions on the parameters of the panel data sample selection model just described and can be tested using standard likelihood ratio or Wald tests.

In our case, equations (1) and (2) -the first block of the CDM model where we analyse the drivers of $R \& D$ (characteristics of the firms and reasons to engage in innovation)-, are jointly estimated using this relatively novel estimator to control for selection bias and unobserved heterogeneity. In these estimations we include the main characteristics such as size (in logs), age, public support, cooperation and foreign capital that, according to the literature, are related to the decision to do R\&D and to the effort. We also include the variables that capture the reasons to innovate or objectives (oriented towards product innovation or process innovation, or reducing environmental impact, or comply with regulations).

The third equation, the second block of the CDM model, where we examine the effect of the different obstacles to innovation, was estimated using a random effects probit model defined as follows:

$$
\begin{gathered}
I N N_{i t}^{*}=\gamma R \& D_{i t}^{*}+\beta W_{i t}+u_{i t} \\
I N N_{i t}=\left\{\begin{array}{c}
1 \text { if } I N N_{i t}^{*}>0 \\
0 \text { otherwise }
\end{array}\right.
\end{gathered}
$$


where $I N N_{i t}^{*}$ is the unobservable variable, $I N N_{i t}$ is the observed outcome, $R \& D_{i t}^{*}$ is the predicted value of the outcome equation (2), $\boldsymbol{W}_{i t}$ is the observed vector of exogenous characteristics which influence $I N N_{i t}^{*}, \gamma$ and $\beta$ are parameters to be estimated. Furthermore, we can decompose the error term into two parts:

$$
u_{i t}=\alpha_{i}+\epsilon_{i t}
$$

here the $\alpha^{\prime} s$ denote individual specific unobservable effects, assuming that $\alpha_{i} \sim$ $\mathrm{N}\left(0, \sigma_{\alpha}^{2}\right)$ and $\epsilon_{i t}$ is the iid $\mathrm{N}(0,1)$ random error. From this specification we know that

$$
\operatorname{Var}\left(u_{i t}\right)=1+\sigma_{\alpha}^{2}
$$

The common error component $\alpha_{i}$ means that, within individuals, the $u_{i t}$ will be correlated by a magnitude

$$
\rho=\frac{\sigma_{\alpha}^{2}}{1+\sigma_{\alpha}^{2}}
$$

Since the realizations of $I N N_{i t}$ are correlated, the common $\alpha_{i}$ mean that the $\mathrm{Ti}$ observations on individual $\mathrm{i}$ are distributed according to a T-variate normal distribution, making the likelihood function extremely complicated. However, Butler and Moffitt (1982) showed that, because the dependence in the $u_{i t}$ is completely due to the common variation in the $\alpha_{i}{ }^{\prime} s$, we can eliminate the higher order integrals by conditioning on the $\alpha_{i}$, and integrate them out of the likelihood. Using this approach we only have to evaluate one-dimensional integrals, again by means of the Gauss-Hermite quadrature approximation.

In this specification, and in order to avoid some potential endogeneity problems, the vector of exogenous characteristics includes the predicted value for the firms' $R \& D$ effort taken from the previous estimations. We also include the size of the firms and the barriers that may hamper innovation. We consider factors related to costs, knowledge and market.

\subsection{Results and discussion}


With the estimation of the R\&D equation with sample selection we examine the effects of the explanatory variables on the decision to engage or not in $R \& D$ and on the relative amount of R\&D expenditure. The results (Table 2) show, first, that size has opposed effects. It is more likely that bigger energy firms engage in R\&D activities but once they carry out R\&D activities, smaller companies devote more resources to R\&D (in relative terms). Empirical analyses of electric utilities have shown that there is a positive and significant effect of the size of the firms on R\&D expenditure (Jamasb and Pollit, 2008). In particular, the econometric estimations that have taken into account the existence of sample selection (Sanyal and Cohen, 2009; Salies, 2010, Kim et al., 2012) have always found a positive and significant relationship between size and the decision to engage in $R \& D$. Although it is necessary to be cautious with the comparisons because of the differences in the samples, our results point in the same direction, showing that there is a critical mass for obtaining profits from $R \& D$ investments in the energy industry. However, the results on the elasticity of R\&D expenditure with respect to size vary significantly in the empirical analyses from values greater than 1 to values less than 1, or even not significant (Sterlacchini, 2102). In this respect, our results lead us to reject the Schumpeterian hypothesis and to favour evidence on the advantage of small firms in R\&D intensity in the energy industry. Among the possible explanations for this result could be the significant reduction in the size of electric utilities after the vertical unbundling and horizontal splitting resulting from liberalisation, which significantly changed the structure of the industry (Jamasb and Pollit, 2008; Salies, 2010)

Second, younger firms engage more than older firms in the decision to perform $R \& D$ and they are also more likely to devote more resources to $R \& D$ activities. Competition has implied more firms in the industry, either because of unbundling or new entrants, and younger firms are among the more intense $R \& D$ performers. Third, having received public support to carry out $R \& D$ projects in the previous period (t-1) has a positive influence both on the decision to perform R\&D and on its intensity.

Finally, the energy firms that claim that process innovation is of great importance are also those that devote greater resources to technological activities. The other innovation 
objectives have no impact on R\&D intensity, with the exception of norms and regulations on environment, health and safety.

These results are consistent with several studies discussed in section 2. In a liberalised energy market, competition forces firms to seek wider margins by means of enhanced productive efficiency, thus embracing process innovations. Research investment is oriented towards short-term objectives and focuses on applied R\&D with the aim of increasing efficiency and profit margins (Defeuilley and Furtado, 2000; Jamasb and Pollit, 2008; Salies, 2010).

\section{TABLE 2}

The estimations for the innovation equation (Table 3) show, as expected, that the main control variables -size and the estimated $R \& D$ intensity resulting from the estimated parameters of the model in Table 2- have positive and highly significant effects on the probability of introducing innovations. The results for the energy industry also show that financial and knowledge obstacles are not important barriers hampering innovation, in contrast to the analyses carried out for firms in general (Mohnen et al., 2008; Savignac, 2008; Blanchard et al., 2013). While empirical evidence has stressed that firms face financial obstacles to innovation activities (Hall, 2002; Popp and Newell, 2012; Blanchard et al., 2013), our results suggest, along the same lines as Salies (2010) in his analysis of European electric utilities, that firms in the energy industry seem not to be subject to financial constraints in carrying out their innovative projects even after the liberalisation reforms ${ }^{4}$.

\section{TABLE 3}

Firms in the energy sector that perceive that the market is dominated by established firms have a lower probability of introducing innovations. The estimations show that the

\footnotetext{
${ }^{4}$ To measure financial constraints and to find the proper indicators at a firm level to carry out empirical research is not free of limitations (Czarnitzki and Hottenrott, 2010; Salies, 2010). In this paper we adopt a direct approach based on the firms' own assessments from the information provided in the CIS in the same way as the rest of the potential barriers (knowledge, market) used in the empirical analysis. In any case this is the only information regarding financial constraints provided by the PITEC. Obtaining other indicators, such as cash flow or dividends, would require merging PITEC with other databases which would be considerably difficult because of anonymity requirements.
} 
parameter is negative and significant, confirming the dominance of existing technologies and the incumbent inertia of the energy system. Despite the current competitive situation, our results show that incumbents in the industry are hampering innovative alternative technology projects. These results suggest that the technology mix of the country may be an entry barrier when incumbent firms concentrate their portfolio on traditional energy technologies. Even if liberalisation has brought about more competition and this in turn has transformed the structure of the energy sector by altering the number and average size of participating firms by renewing the technologies for generation as well as introducing increased rivalry in retail, the main barriers hindering innovation in the sector are related to the perception of incumbent dominance in the energy market.

For the other market obstacle, the uncertainty of the demand, the parameter is significant and positive. Nevertheless, this only holds for product and not for process innovation. Therefore there is a positive relationship between the firms that state that demand uncertainty is a significant obstacle and the most innovative firms, in terms of new products, showing that although they face this obstacle, it does not hamper their innovation activities. These kinds of innovation are mainly related to the liberalisation process and increasing competition in the retail energy markets, where suppliers are offering more innovative goods, and particularly services, to consumers. In liberalised markets, characterised by the existence of greater uncertainties than in monopoly conditions, new players have entered. The supplier companies, with more freedom to design products and prices, are developing a variety of new, more customer oriented, energy services (Markard and Truffer, 2006). Competition in the residential electricity markets tends to be initiated by a few smaller players who offer innovation and over time incumbent firms, that show quite considerable initial resistance, also deliver more innovative services to customers (Littlechild, 2006; Markard and Truffer, 2006).

\subsection{Robustness checks}

Overall, the results presented in the last subsection suggest that it is more likely that larger firms engage in $\mathrm{R} \& \mathrm{D}$ activities, although smaller firms devote proportionally more resources to it. In addition, younger firms tend to be more active in and also allocate more resources to technological activities than older firms; public support is 
important in explaining engagement and $R \& D$ intensity, which in turn are strongly correlated with energy firms' efforts towards introducing process innovations.

Several issues can be affecting the results. As discussed in section 3, the introduction of the variable public funds into the selection equation -even its lagged value- raises some endogeneity concerns given the fact that to obtain public support for R\&D projects, firms must have carried out prior $R \& D$ activities. In order to avoid this issue, we have re-estimated the model without public funds in the selection equation. Table 4 shows the results of this specification where it can be seen that the main insights remain unchanged from our baseline model presented in the previous sub-section. Hence, the endogeneity of public support is not conditioning the main results. It is important to note that this new econometric specification also provides similar results for the innovation equation (panel $\mathrm{b}$ in table 4). When equation 3 is re-estimated using the results in the upper panel of table 4, all the results remain qualitatively unchanged: size and R\&D effort are important determinants of the probability of innovation. Energy firms do not face financial or knowledge barriers but on the other hand they are confronted with significant market barriers.

\section{TABLE 4}

An additional concern regarding the results of the baseline model is related to the effects of barriers to innovation on the firms' entire decision making process regarding R\&D activities. The perception of obstacles -especially financial obstacles- might well affect the decision to invest in $\mathrm{R} \& \mathrm{D}$. Moreover, accepting that this is a long-term, structural decision, it surely affects the amount of resources that firms devote to $R \& D$ investments. In order to take this into account, we estimate a variant of our baseline model including costs barriers in the intensity equation (specification a) in table 5). The results for both stages of the CDM model remain qualitatively identical to those of the baseline model. Acknowledging, as before, a potential endogeneity issue regarding the introduction of public funds, we re-estimate a variant of our first robustness check but conserve the financial barriers variable (specification b) in table 5). Again, with minor changes vis-à-vis the baseline specification, the most relevant results remain unaltered, especially those referring to the innovation equation. With all the specifications tried so far, neither financial nor knowledge barriers are relevant constraints to innovation for 
energy firms. On the other hand, the perception that the market is dominated by incumbents significantly reduces the probability of introducing innovations in the energy industry.

\section{TABLE 5}

For the estimations of the innovation equation, we have performed additional robustness checks to take into account some discussions in the literature on R\&D and innovation. Firstly, R\&D investments may require some time to have an effect on innovation in processes and products. Therefore, we switched the predicted $R \& D$ effort from the first block, which considered a contemporaneous correlation between R\&D effort and innovation outcomes, to the corresponding lagged value (t-1). In this case, the results shown in table 6- are consistent with the previous ones. Secondly, in order to account for possible systematic correlations between decisions to perform product and process innovations (Martínez-Ros and Labeaga, 2009) we estimate a bivariate probit model with binary equations for each outcome. In this case, the only possibility of carrying out the estimations is to use pooled data. Hence we are not able to control for individual effects in these estimations. The results from our first estimation are also confirmed and show the relevance of market obstacles to innovation and the differences regarding process or product innovation (table 7). The estimate for the cross equation correlation is positive, indicating complementarities between the two decisions.

\section{TABLES 6 and 7}

\section{CONCLUSIONS}

There is a broad consensus on the desirability of the energy industry devoting more resources to $R \& D$ and innovation. To meet the challenge related to climate change will require a significant increase in energy innovation. The objective of this paper is to improve our understanding of the reasons behind $R \& D$ investment and innovation in the energy sector. Putting together two strands of the literature on the determinants of innovation, we have analysed the influence of the characteristics of the firms and the objectives of innovation on $\mathrm{R} \& \mathrm{D}$ decisions and effort and, particularly, what barriers are hampering innovation in this sector. 
The econometric analysis has been carried using panel data for the period 2004-2010 and the main conclusions from the estimations regarding $R \& D$ drivers and obstacles to innovation in the energy industry are as follows. Firstly, our joint estimations for the decision to spend on $R \& D$ or not and the $R \& D$ effort show, as does the literature, that small size is a barrier to entry for R\&D in the energy sector. Nevertheless, there is no positive relationship between size and $R \& D$ intensity. Once they carry out $R \& D$, smaller companies make a greater effort in $R \& D$, measured in relative terms with respect to sales. Secondly, younger firms are more likely to perform R\&D and to make a greater $R \& D$ effort. Thirdly, $R \& D$ intensity is particularly related to innovation objectives oriented to process innovation likely to increase efficiency through a reduction of costs or to an increase in production capacity.

The estimations of the innovation equation provide the main conclusions of the paper regarding the obstacles to innovation. Firstly, our results show that the main barrier hampering innovation activities in the energy industry is the market dominance of established firms. Secondly, the estimations for product innovations show that although the most innovative firms state that they are facing an uncertain demand for innovative goods and particularly services, this obstacle is not hampering their innovative activities. Thirdly, and in contrast to the results in the literature for other industries, financial constraints are not a significant obstacle to innovation in the energy industry.

The analysis of R\&D drivers and obstacles to innovation was carried out for the energy industry. However, other industries such as component suppliers, the machinery industry and transport equipment also play an important role in energy innovation. To include these sectors in the analysis would require further research and enough information to be able to differentiate their $R \& D$ and innovative activities related with energy from those not related to this sector. In the analysis carried out it should be also taken into account that the available information does not allow differentiation between the firms that perform their activity in the absolutely liberalised segments of the energy market from those in segments where some regulation exists. To distinguish between these types of firm would allow an analysis of whether there are some differences in their R\&D and innovative behaviour. An additional limitation is that the sample 
includes all the gas and electricity energy firms operating at all the phases of the industrial process without it being possible to distinguish between them.

Finally, the results have some policy implications regarding how to increase R\&D efforts and innovation in the energy sector. The general rationale for policy support to $R \& D$ and innovation is the existence of market failures. Together with this justification for policy action, our results show there are important barriers particular to the energy industry related to the dominance of established firms in the market and existing technologies that hamper innovation efforts significantly. 
Acknowledgements: We are very grateful for the suggestions and comments from two anonymous referees that were very useful for improving the paper. The authors would like to thank P. Arqué, J. Batalla, L. Blázquez, P. Castells, M.D. Gadea, R. Huisman, J. P. Montero, G. Pellegrino and E. Trujillo for valuable comments. Previous versions of this paper were presented at the VIII Conference of the Spanish Association for Energy Economics (Valencia, Spain, January 2013); at the XVI Applied Economics Meeting (Granada, Spain, June 2013); and at the Mannheim Energy Conference 2013 (Mannheim, Germany, June 2013). We would like to thank the participants at these meetings for their helpful comments. We acknowledge financial support from the Chair on Energy and Environmental Sustainability, University of Barcelona. 


\section{References}

Anadon, L., Bunn, M., Chan, G., Chan, M., Jones, C., Kempener, R., Lee, A., Logar, N., Narayanamurti, V., 2011. Transforming U.S. energy innovation. Energy Technology Innovation Policy research group. Belfer Center for Social and International Affairs, Harvard Kennedy School, Cambridge, MA.

Anadon, L., 2012. Missions-oriented RD\&D institutions in energy between 2000 and 2010: A comparative analysis of China, the United Kingdom, and the United States, Research Policy 41, 1742-1756.

Arellano, M. and Honoré, B., 2001. Panel data models: Some recent developments, in: Heckman, J. J., Leamer, E. (Eds), Handbook of Econometrics. North Holland: Amsterdam.

Artés, J., 2009. Long-run versus short-run decisions, R\&D and market structure in Spanish firms. Research Policy 38, 120-132.

Barge-Gil, A., 2010. Cooperation-based innovators and peripheral co-operators: An empirical analysis of their characteristics and behaviour. Technovation 30, 195-206.

Baumol, W. J., Litan R. E., Schramm, C. J., 2007. Good Capitalism, Bad Capitalism. New Haven. Yale University Press.

Becheikh, N., Landry, R., Amara, N., 2006. Lessons from innovation empirical studies in the manufacturing sector: A systematic review of the literature from 1993-2003. Technovation 26, 644-664.

Blanchard, P., Huiban, J.P., Musolesi, A. and Sevestre, P., 2013. Where there is a will, there is a way? Assessing the impact of obstacles to innovation. Industrial and Corporate Change 22, 679-710.

Butler, J. S. and Moffitt, R., 1982. A Computationally Efficient Quadrature Procedure for the One-Factor Multinomial Probit Model, Econometrica 50-3, 761-764.

Callejón, M., García-Quevedo, J., 2005. Public Subsidies to Business R\&D: Do they Stimulate Private Expenditures? Environment and Planning C: Government and Policy 23, 279-293.

Cohen, W., 2010. Fifty years of empirical studies of innovative activity and performance, in: Hall, B., Rosenberg, N. Handbook of the Economics of Innovation, Elsevier.

Crepon, B., Duguet, E., Mairesse, J., 1998. Research, innovation and productivity: an econometric analysis at the firm level. Economics of Innovation and New Technology 7, 115-158.

Cumming, D., Macintosh, J., 2000. The determinants of R\&D expenditures: A study of the Canadian biotechnology industry. Review of Industrial Organization 17, 357-370.

Czarnitzki, D., Hottenrott, H., 2010. Financing constraints for industrial innovation: What do we know?. Review of Business and Economics 55, 346-362.

David, P., Hall, B., Toole, A., 2000. Is public R\&D a complement or substitute for private R\&D? A review of the econometric evidence. Research Policy 29, 497-529.

Defeuilley, C., Furtado, A. T., 2000. Impacts de l'ouverture à la concurrence sur la R\&D dans le secteur électrique. Annals of Public and Cooperative Economics 71, 5-27. 
D'Este, P., Iammarino, S., Savona, M., von Tunzelmann, N., 2012. What hampers innovation? Revealed barriers versus deterring barriers. Research Policy 41, 482-488.

De Marchi, V., 2012. Environmental innovation and R\&D cooperation: Empirical evidence from Spanish manufacturing firms. Research Policy 41, 614-623.

Dooley, J., 1998. Unintended consequences: Energy R\&D in a deregulated energy market. Energy Policy 26, 547-555.

Doraszelski, U., Jaumandreu, J., 2013. R\&D and productivity: Estimating endogenous productivity. Review of Economic Studies 80, 1338-1383.

Economics for Energy, 2013. Innovación en energía en España. Análisis y recomendaciones. Informe 2012. Economics for Energy, Vigo, Spain.

European Commission, 2009a. SEC (2009). 1297. Impact assessment for the communication on investing in the development of low carbon technologies (SETPlan), Brussels.

European Commission, 2009b. SEC (2009) 287 Report on progress in creating the internal gas and electricity market. Technical annex to the communication from the Commission to the Council and the European Parliament. COM (2009) 115, Brussels.

Gallagher, K., Grübler, A., Kuhl, L. Nemet, G., Wilson, Ch., 2102. The energy technology innovation system. Annual Review of Environmental Resources 37, 137162.

García-Quevedo, J., Pellegrino, G., Vivarelli, M., 2014. R\&D drivers and age? Are young firms different? Research Policy 43, 1544-1556.

Gayle, G. L., Viauroux, C., 2007. Root-n consistent semiparametric estimators of a dynamic panel-sample-selection model. Journal of Econometrics 141, 179-212.

GEA, 2012. Global Energy Assessment. Towards a sustainable future, Cambridge University Press, Cambridge, UK and New York, USA.

Griffith, R., Huergo, E., Mairesse, J., Peters, B., 2006. Innovation and productivity across four European Countries. Oxford Review of Economic Policy 22, 483-498.

Hall, B., 2002. The financing of research and development. Oxford Review of Economic Policy 18, 37-51.

Hall, B., Lotti, F., Mairesse, J., 2009. Innovation and productivity in SMEs: empirical evidence for Italy. Small Business Economics 33, 13-33.

Hall, B., Lotti, F., Mairesse, J., 2013. Evidence on the impact of R\&D and ICT investments on innovation and productivity in Italian firms. Economics of Innovation and New Technology 22, 300-328.

Henderson, R. M., Newell, R. G., 2011. Accelerating Energy Innovation: Insights from Multiple Sectors. University of Chicago Press.

IEA 2012. World Energy Outlook. International Energy Agency, OECD.

Jalivand, A., Kim, S., 2012. Corporate Flexibility, Investment Strategies and performance under Turbulent Environment: New Perspectives. Working paper, Quinlan School of Bussines, Loyola University Chicago.

Jamasb, T., Pollitt, M., 2008. Liberalisation and R\&D in network industries: The case of the electricity industry. Research Policy 37, 995-1008. 
Kim, J., Kim, Y., Flacher, D., 2012. R\&D investment of electricity-generating firms following industry restructuring. Energy Policy 48, 103-117.

Littlechild, S., 2006. Competition and contracts in the Nordic residential electricity markets. Utilities Policy 14, 135-147.

Markard, J., Truffer, B., 2006. Innovation processes in large technical systems: Market liberalization as a driver for radical change? Research Policy 35, 609-625.

Martínez-Ros, E., Labeaga, J., 2009. Product and process innovation: Persistence and complementarities. European Management Review 6, 64-75.

Mohnen, P., Palm, F., van der Loeff, S., Tiwari, A., 2008. Financial Constraints and Other Obstacles: are they a Threat to Innovation Activity? De Economist 156, 201-214.

Mohnen, P. and Hall, B. 2013. Innovation and productivity: An update. UNU-Merit Working Paper 2013-021.

Molero, J., 2012. La importancia económica de innovar en el sector de la energía. Cuadernos de Energía 34, 77-83.

Mulder, M., Shestalova, V., Zwart, G., 2006. Liberalisation of European energy markets: challenges and policy options. CPB Document No. 138, CPB Netherlands Bureau for Economic Policy Analysis.

Musolesi, A. and Huiban, J. P., 2010. Innovation and productivity in knowledge intensive business services, Journal of Productivity Analysis 34, 63-81.

Nakicenovic, N., Nordhaus, W., 2011. Editor's introduction: The economics of technologies to combat global warming. Energy Economics 33, 565-571.

Newell, R. G., 2010. The role of markets and policies in delivering innovation for climate change mitigation. Oxford Review of Economic Policy 26, 253-269.

Neyman, J. and Scott, E. L., 1948. Consistent estimates based on partially consistent observations. Econometrica 16, 1-32.

OECD, 2005. Oslo Manual. The measurement of scientific and technological activities. Proposed guidelines for collecting and interpreting technological innovation data. $3^{\text {rd }}$ Edition. OECD Publishing.

OECD, 2011. Fostering innovation for green growth. Organisation for Economic Cooperation and Development, Paris.

Pellegrino, G., Savona, M., 2013. Is money all? Financing versus knowledge and demand constraints to innovation. SPRU Working Paper Series SWPS 2013-01.

Popp, D., Newell, R., 2012. Where does energy R\&D come from? Examining crowding out from energy R\&D. Energy Economics 34, 980-991.

Raymond, W., Mohnen, P., Palm, F. and van der Loeff, S., 2007. The Behavior of the Maximum Likelihood Estimator of Dynamic Panel Data Sample Selection Models, CESIFO Working Paper no. 192.

Raymond, W. Mohnen, P. Palm, F., van der Loeff, S., 2010 Persistence of Innovation in Dutch Manufacturing: Is It Spurious? Review of Economics and Statistics 92, 495-504.

Salies, E., 2010. A test of the Schumpeterian hypothesis in a panel of European Electric Utilities, in: J.L Gaffard, J.L., Salies, E., Innovation, Economic Growth and the Firm. Edward Elgar Publishing. 
Salies, E., Nesta, L., 2010. Libéralisation et dépôts de brevets verts des utilités électriques en Europe. Documents de Travail de l'OFCE No. 2010-21. Observatoire Francais des Conjonctures Economiques (OFCE).

Sanyal, P., 2007. The effect of deregulation on environmental research by electric utilities. Journal of Regulatory Economics 31, 335-353.

Sanyal, P., Cohen, L. R., 2009. Powering Progress: Restructuring, Competition, and R\&D in the U.S. Electric Utility Industry. The Energy Journal 30, 41-79.

Sanyal, P., Ghosh, S., 2013. Product Market Competition and Upstream Innovation: Evidence from the U.S. Electricity Market Deregulation. Review of Economics and Statistics 95, 237-254.

Savignac, F. 2008. Impact of Financial Constraints on Innovation: What Can Be Learned from a Direct Measure? Economics of Innovation and New Technology 17, 553-69.

Segarra, A., 2010. Innovation and productivity in manufacturing and service firms in Catalonia: a regional approach. Economics of Innovation and New Technology 19, 233258.

Sterlacchini, A., 2012. Energy R\&D in private and state-owned utilities: An analysis of the major world electric companies. Energy Policy 41, 494-506. 
Table 1. Descriptive statistics

\begin{tabular}{|c|c|c|c|c|c|c|}
\hline Variable & Description & $\mathbf{N}$ & Mean & Std. Dev. & Min & Max \\
\hline $\mathrm{R} \& \mathrm{D}$ decision & $\begin{array}{l}\text { Dummy = } 1 \text { if the firm has } \\
\text { performed technological } \\
\text { activities }\end{array}$ & 410 & 0.591 & 0.492 & 0 & 1 \\
\hline $\mathrm{R} \& \mathrm{D}$ effort* & R\&D expenditure over sales & 410 & 1.7 & 6.8 & 0 & 54.3 \\
\hline Size* & Number of employees & 410 & 611 & 1121 & 1 & 7900 \\
\hline Age & $\begin{array}{l}\text { Years the firm has been } \\
\text { operating in the market }\end{array}$ & 327 & 31.0 & 33.2 & 0 & 110 \\
\hline Public funds & $\begin{array}{l}\text { Dummy }=1 \text { if the firm } \\
\text { received an R\&D subsidy }\end{array}$ & 410 & 0.419 & 0.494 & 0 & 1 \\
\hline Foreign capital & $\begin{array}{l}\text { Dummy }=1 \text { if the firm is } \\
\text { partially owned by foreign } \\
\text { investors }\end{array}$ & 410 & 0.160 & 0.367 & 0 & 1 \\
\hline Cooperation & $\begin{array}{l}\text { Dummy }=1 \text { if the firm } \\
\text { cooperates in innovation }\end{array}$ & 334 & 0.574 & 0.495 & 0 & 1 \\
\hline Group & $\begin{array}{l}\text { Dummy }=1 \text { if the firm } \\
\text { belongs to a group of firms }\end{array}$ & 410 & 0.654 & 0.476 & 0 & 1 \\
\hline Objective: Product & $\begin{array}{l}\text { Dummy }=1 \text { if the firm } \\
\text { considers the objective of } \\
\text { high importance }\end{array}$ & 334 & 0.189 & 0.392 & 0 & 1 \\
\hline Objective: Process & $\begin{array}{l}\text { Dummy }=1 \text { if the firm } \\
\text { considers the objective of } \\
\text { high importance }\end{array}$ & 334 & 0.204 & 0.403 & 0 & 1 \\
\hline Objective: Environment & $\begin{array}{l}\text { Dummy }=1 \text { if the firm } \\
\text { considers the objective of } \\
\text { high importance }\end{array}$ & 334 & 0.380 & 0.486 & 0 & 1 \\
\hline Objective: Norms & $\begin{array}{l}\text { Dummy = } 1 \text { if the firm } \\
\text { considers the objective of } \\
\text { high importance }\end{array}$ & 334 & 0.308 & 0.463 & 0 & 1 \\
\hline Total innovation & $\begin{array}{l}\text { Dummy }=1 \text { if the firm has } \\
\text { performed either product or } \\
\text { process innovation }\end{array}$ & 410 & 0.739 & 0.440 & 0 & 1 \\
\hline Process innovation & $\begin{array}{l}\text { Dummy = } 1 \text { if the firm has } \\
\text { performed process } \\
\text { innovation }\end{array}$ & 410 & 0.656 & 0.476 & 0 & 1 \\
\hline Product innovation & $\begin{array}{l}\text { Dummy }=1 \text { if the firm has } \\
\text { performed product } \\
\text { innovation }\end{array}$ & 410 & 0.390 & 0.488 & 0 & 1 \\
\hline Cost barriers & $\begin{array}{l}\text { Dummy }=1 \text { if the firm } \\
\text { considers the barrier to be of } \\
\text { high importance }\end{array}$ & 410 & 0.066 & 0.248 & 0 & 1 \\
\hline Knowledge barriers & $\begin{array}{l}\text { Dummy = } 1 \text { if the firm } \\
\text { considers the barrier to be of } \\
\text { high importance }\end{array}$ & 410 & 0.005 & 0.070 & 0 & 1 \\
\hline Market: Incumbents & $\begin{array}{l}\text { Dummy }=1 \text { if the firm } \\
\text { considers the barrier to be of } \\
\text { high importance }\end{array}$ & 410 & 0.095 & 0.294 & 0 & 1 \\
\hline $\begin{array}{l}\text { Market: Demand } \\
\text { uncertainty }\end{array}$ & $\begin{array}{l}\text { Dummy = } 1 \text { if the firm } \\
\text { considers cost barriers to be } \\
\text { of high importance }\end{array}$ & 410 & 0.090 & 0.287 & 0 & 1 \\
\hline
\end{tabular}

\footnotetext{
* In the regressions these continuous variables have been transformed in logarithms.
} 
Table 2. R\&D equation (decision and intensity)

\begin{tabular}{lcc}
\hline & R\&D & R\&D \\
& Intensity & Decision \\
\hline \multirow{2}{*}{ Size } & $-0.869^{* * *}$ & $0.295^{* * *}$ \\
& $(0.0627)$ & $(0.0921)$ \\
Age & $-0.00751^{* * *}$ & $-0.00760^{*}$ \\
Public funds (t-1) & $(0.00239)$ & $(0.00457)$ \\
& $0.399^{* *}$ & $1.200^{* * *}$ \\
Foreign capital & $(0.183)$ & $(0.233)$ \\
& $0.598^{* * *}$ & 0.495 \\
Cooperation & $(0.207)$ & $(0.318)$ \\
Objectives: & 0.181 & \\
Product innovation & $(0.210)$ & \\
Process innovation & -0.384 & \\
Environmental impact & $(0.242)$ & \\
Norms and regulations & $1.536^{* * *}$ & \\
Constant & $(0.243)$ & \\
& -0.223 & \\
Observations & $(0.176)$ & $(0.611)$ \\
\end{tabular}

Tests of sample selection and individual effects:
$\rho_{a_{1} a_{2}}$
$0.265(0.170)$
$\rho_{\varepsilon_{1} \varepsilon_{2}}$
$0.592 * *(0.259)$
$\sigma_{a_{1}}$
$-0.0800(0.142)$
$\sigma_{a_{2}}$
$0.357 * * *(0.0886)$
$\sigma_{\epsilon_{2}}$
$0.0535(0.0615)$

Note: All regressions include time dummies to control for year-specific effects and firm individual effects. Standard errors in parentheses and $* * *$ indicate significant at $1 \%$, ** indicate significant at $5 \%$ and $*$ indicate significant at $10 \%$. 


\begin{tabular}{|c|c|c|c|}
\hline & \multicolumn{3}{|c|}{ Innovation: } \\
\hline & Total & Process & Product \\
\hline \multirow[t]{2}{*}{ Size } & $0.487 * * *$ & $0.542 * * *$ & $0.218^{*}$ \\
\hline & $(0.138)$ & $(0.146)$ & $(0.121)$ \\
\hline \multirow[t]{2}{*}{ Predicted R\&D effort } & $1.336 * * *$ & $1.497 * * *$ & $0.395^{*}$ \\
\hline & $(0.294)$ & $(0.319)$ & $(0.218)$ \\
\hline \multirow[t]{2}{*}{ Group } & 0.541 & 0.372 & 0.392 \\
\hline & $(0.386)$ & $(0.426)$ & $(0.410)$ \\
\hline \multicolumn{4}{|l|}{ Barriers: } \\
\hline \multirow[t]{2}{*}{ Cost } & -0.0599 & 0.0380 & -0.311 \\
\hline & $(0.466)$ & $(0.479)$ & $(0.422)$ \\
\hline \multirow[t]{2}{*}{ Knowledge } & -1.234 & -0.331 & 0.994 \\
\hline & $(1.835)$ & $(1.875)$ & $(1.362)$ \\
\hline \multicolumn{4}{|l|}{ Market: } \\
\hline Incumbents & $-1.522 * * *$ & $-1.217 * *$ & -0.813 \\
\hline & $(0.535)$ & $(0.562)$ & $(0.535)$ \\
\hline Demand uncertainty & $1.239 * *$ & 0.394 & $1.275 * * *$ \\
\hline & $(0.598)$ & $(0.573)$ & $(0.440)$ \\
\hline Constant & $\begin{array}{c}-2.397 * * * \\
(0.705)\end{array}$ & $\begin{array}{c}-3.296 * * * \\
(0.803)\end{array}$ & $\begin{array}{c}-2.487 * * * \\
(0.697)\end{array}$ \\
\hline \multirow[t]{2}{*}{$\rho$} & $0.805^{*}$ & $1.067 * * *$ & $1.061 * * *$ \\
\hline & $(0.450)$ & $(0.410)$ & $(0.359)$ \\
\hline Log-likelihood & -172.7 & -203.4 & -253.5 \\
\hline chi2 & 37.34 & 36.92 & 22.60 \\
\hline Prob(chi2) & 0.000367 & 0.000427 & 0.0467 \\
\hline Observations & & 410 & \\
\hline
\end{tabular}

Note: All regressions include time dummies to control for year-specific effects and firm individual effects. Standard errors in parentheses and $* * *$ indicate significant at $1 \%$, ** indicate significant at $5 \%$ and $*$ indicate significant at $10 \%$. 
Table 4. Robustness check: lag of public funds only in intensity equation

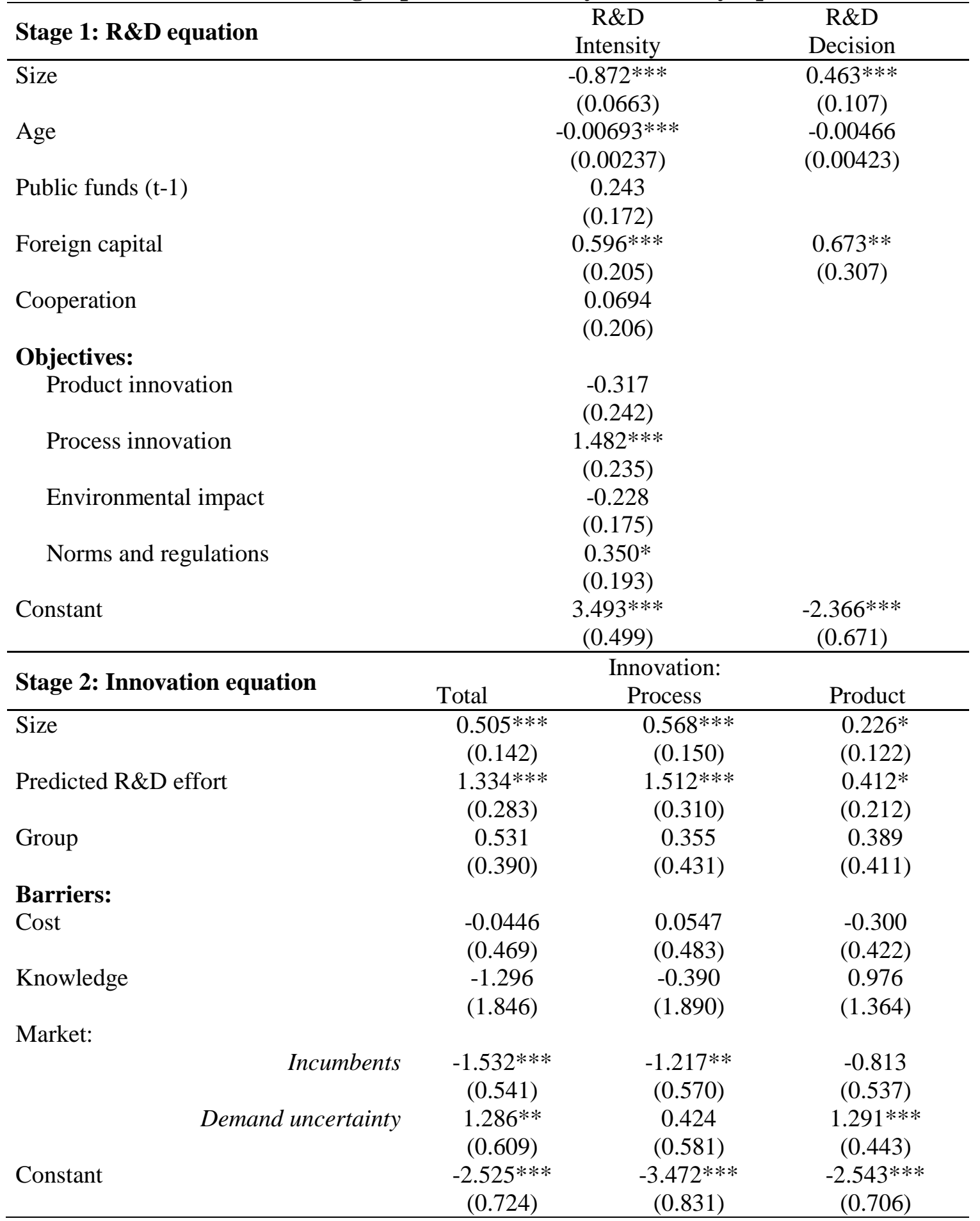

Note: The number of observations is the same as in tables 2 and 3. For brevity, given the similarity of results between the robustness checks and the baseline model the coefficients for the test of sample selection and individual effects of stage 1 as well as those for goodness of fit of stage 2 are omitted. All regressions include time dummies to control for year-specific effects and firm individual effects. Standard errors in parentheses and $* * *$ indicate significant at $1 \%, * *$ indicate significant at $5 \%$ and $*$ indicate significant at $10 \%$. 
Table 5. Robustness check: introducing cost barriers into the intensity equation

\begin{tabular}{|c|c|c|c|c|c|c|}
\hline \multirow{3}{*}{\multicolumn{2}{|c|}{ Stage 1: $R \& D$ equation }} & \multicolumn{3}{|c|}{ Specification a) } & \multicolumn{2}{|c|}{ Specification b) } \\
\hline & & \multirow{2}{*}{$\begin{array}{c}\text { R\&D } \\
\text { Intensity }\end{array}$} & \multirow{2}{*}{\multicolumn{2}{|c|}{$\begin{array}{c}\text { R\&D } \\
\text { Decision }\end{array}$}} & $\mathrm{R} \& \mathrm{D}$ & R\&D \\
\hline & & & & & Intensity & Decision \\
\hline \multirow{2}{*}{\multicolumn{2}{|c|}{ Size }} & \multirow{2}{*}{$\begin{array}{c}-0.870 * * * \\
(0.0628)\end{array}$} & \multicolumn{2}{|c|}{$0.294 * * *$} & $-0.791 * * *$ & $0.481 * * *$ \\
\hline & & & \multicolumn{2}{|c|}{$(0.0910)$} & $(0.0903)$ & $(0.100)$ \\
\hline \multirow{2}{*}{\multicolumn{2}{|c|}{ Age }} & \multirow{2}{*}{$\begin{array}{c}-0.00751 * * * \\
(0.00239)\end{array}$} & \multirow{2}{*}{\multicolumn{2}{|c|}{$\begin{array}{c}-0.00775^{*} \\
(0.00456)\end{array}$}} & 0.000272 & -0.00137 \\
\hline & & & & & $(0.00332)$ & $(0.00367)$ \\
\hline \multirow{2}{*}{\multicolumn{2}{|c|}{ Public funds (t-1) }} & $0.408 * *$ & \multirow{2}{*}{\multicolumn{2}{|c|}{$\begin{array}{c}1.200 * * * \\
(0.232)\end{array}$}} & $0.414 * *$ & \\
\hline & & $(0.184)$ & & & $(0.193)$ & \\
\hline \multicolumn{2}{|l|}{ Foreign capital } & $0.583^{* * *}$ & \multirow{2}{*}{\multicolumn{2}{|c|}{$\begin{array}{c}0.495 \\
(0.318)\end{array}$}} & $0.537 * *$ & $0.551 * *$ \\
\hline & & $(0.208)$ & & & $(0.221)$ & $(0.269)$ \\
\hline \multicolumn{2}{|l|}{ Cooperation } & 0.198 & & & 0.0937 & \\
\hline & & $(0.213)$ & & & $(0.231)$ & \\
\hline \multirow{2}{*}{\multicolumn{2}{|c|}{ Cost barriers }} & 0.233 & & & 0.611 & \\
\hline & & $(0.377)$ & & & $(0.413)$ & \\
\hline \multicolumn{7}{|l|}{ Objectives: } \\
\hline \multicolumn{2}{|l|}{ Product innovation } & $\begin{array}{l}-0.395 \\
(0.242)\end{array}$ & & & $\begin{array}{l}-0.340 \\
(0.256)\end{array}$ & \\
\hline \multicolumn{2}{|l|}{ Process innovation } & $\begin{array}{c}1.545 * * * \\
(0.243)\end{array}$ & & & $\begin{array}{c}1.408 * * * \\
(0.240)\end{array}$ & \\
\hline \multicolumn{2}{|c|}{ Environmental impact } & $\begin{array}{l}-0.230 \\
(0.176)\end{array}$ & & & $\begin{array}{l}-0.221 \\
(0.186)\end{array}$ & \\
\hline \multicolumn{2}{|c|}{ Norms and regulations } & $\begin{array}{c}0.394 * * \\
(0.193)\end{array}$ & & & $\begin{array}{c}0.494 * * \\
(0.212)\end{array}$ & \\
\hline \multicolumn{2}{|l|}{ Constant } & $\begin{array}{c}3.160 * * * \\
(0.462)\end{array}$ & \multicolumn{2}{|c|}{$\begin{array}{c}-1.606 * * * \\
(0.606)\end{array}$} & $\begin{array}{c}2.847 * * * \\
(0.665)\end{array}$ & $\begin{array}{c}-2.457 * * * \\
(0.601)\end{array}$ \\
\hline \multirow{3}{*}{$\begin{array}{l}\text { Stage 2: Innovation } \\
\text { equation }\end{array}$} & \multicolumn{3}{|c|}{ Specification a) } & \multicolumn{3}{|c|}{ Specification b) } \\
\hline & & [nnovation: & & & Innovation: & \\
\hline & Total & Process & Product & Total & Process & Product \\
\hline Size & $\begin{array}{c}0.487 * * * \\
(0.138)\end{array}$ & $\begin{array}{c}0.543 * * * \\
(0.146)\end{array}$ & $\begin{array}{l}0.217 * \\
(0.121)\end{array}$ & $\begin{array}{c}0.507 * * * \\
(0.141)\end{array}$ & $\begin{array}{c}0.563 * * * \\
(0.148)\end{array}$ & $\begin{array}{l}0.226^{*} \\
(0.122)\end{array}$ \\
\hline Predicted R\&D effort & $\begin{array}{c}1.339 * * * \\
(0.296)\end{array}$ & $\begin{array}{c}1.503 * * * \\
(0.320)\end{array}$ & $\begin{array}{l}0.390 * \\
(0.218)\end{array}$ & $\begin{array}{c}1.511 * * * \\
(0.307)\end{array}$ & $\begin{array}{c}1.676 * * * \\
(0.328)\end{array}$ & $\begin{array}{c}0.458 * * \\
(0.223)\end{array}$ \\
\hline Group & $\begin{array}{c}0.540 \\
(0.387)\end{array}$ & $\begin{array}{c}0.372 \\
(0.427)\end{array}$ & $\begin{array}{c}0.393 \\
(0.410)\end{array}$ & $\begin{array}{c}0.510 \\
(0.390)\end{array}$ & $\begin{array}{c}0.326 \\
(0.427)\end{array}$ & $\begin{array}{c}0.392 \\
(0.412)\end{array}$ \\
\hline Barriers: & & & & & & \\
\hline Cost & $\begin{array}{r}-0.0900 \\
(0.470)\end{array}$ & $\begin{array}{c}-0.00268 \\
(0.483)\end{array}$ & $\begin{array}{l}-0.329 \\
(0.420)\end{array}$ & $\begin{array}{l}-0.111 \\
(0.480)\end{array}$ & $\begin{array}{l}-0.0412 \\
(0.495)\end{array}$ & $\begin{array}{l}-0.342 \\
(0.418)\end{array}$ \\
\hline Knowledge & $\begin{array}{l}-1.212 \\
(1.845)\end{array}$ & $\begin{array}{l}-0.289 \\
(1.884)\end{array}$ & $\begin{array}{c}1.007 \\
(1.363)\end{array}$ & $\begin{array}{l}-1.406 \\
(1.944)\end{array}$ & $\begin{array}{l}-0.454 \\
(1.967)\end{array}$ & $\begin{array}{c}0.985 \\
(1.368)\end{array}$ \\
\hline Market: & & & & & & \\
\hline Incumbents & $\begin{array}{c}-1.517 * * * \\
(0.535)\end{array}$ & $\begin{array}{c}-1.209 * * \\
(0.562)\end{array}$ & $\begin{array}{l}-0.811 \\
(0.535)\end{array}$ & $\begin{array}{c}-1.486 * * * \\
(0.536)\end{array}$ & $\begin{array}{c}-1.151^{* *} \\
(0.562)\end{array}$ & $\begin{array}{l}-0.794 \\
(0.537)\end{array}$ \\
\hline Demand uncertainty & $\begin{array}{c}1.232 * * \\
(0.599)\end{array}$ & $\begin{array}{c}0.380 \\
(0.576)\end{array}$ & $\begin{array}{c}1.270 * * * \\
(0.440)\end{array}$ & $\begin{array}{l}1.295 * * \\
(0.611)\end{array}$ & $\begin{array}{c}0.414 \\
(0.579)\end{array}$ & $\begin{array}{c}1.287 * * * \\
(0.442)\end{array}$ \\
\hline Constant & $-2.395 * * *$ & $\begin{array}{c}- \\
3.296 * * * \\
(0.804)\end{array}$ & $\begin{array}{c}- \\
2.480^{* * * *} \\
(0.697)\end{array}$ & $-2.562 * * *$ & $-3.466 * * *$ & $-2.548 * * *$ \\
\hline
\end{tabular}

Note: The number of observations is the same as in tables 2 and 3. For brevity, given the similarity of results between the robustness checks and the baseline model the coefficients for the test of sample selection and individual effects of stage 1 as well as those for goodness of fit of stage 2 are omitted. All regressions include time dummies to control for year-specific effects and firm individual effects. Standard errors in parentheses and $* * *$ indicate significant at $1 \%, * *$ indicate significant at $5 \%$ and $*$ indicate significant at $10 \%$. 
Table 6. Robustness check for the Innovation equation: lag predicted R\&D effort

\begin{tabular}{|c|c|c|c|}
\hline & \multicolumn{3}{|c|}{ Innovation: } \\
\hline & Total & Process & Product \\
\hline \multirow[t]{2}{*}{ Size } & $0.386 * *$ & $0.337 * *$ & $0.350^{*}$ \\
\hline & $(0.171)$ & $(0.165)$ & $(0.200)$ \\
\hline \multirow[t]{2}{*}{ Lag R\&D effort (t-1) } & $0.570^{* *}$ & $0.548^{*}$ & 0.200 \\
\hline & $(0.284)$ & $(0.284)$ & $(0.330)$ \\
\hline \multirow[t]{2}{*}{ Group } & $1.257^{* *}$ & 0.967 & 0.288 \\
\hline & $(0.608)$ & $(0.603)$ & $(0.701)$ \\
\hline \multicolumn{4}{|l|}{ Barriers: } \\
\hline \multirow[t]{2}{*}{ Cost } & -0.513 & -0.638 & -0.494 \\
\hline & $(0.563)$ & $(0.551)$ & $(0.568)$ \\
\hline \multirow[t]{2}{*}{ Knowledge } & 0.0760 & 0.283 & 2.963 \\
\hline & (2.030) & $(2.000)$ & (1.832) \\
\hline \multicolumn{4}{|l|}{ Market: } \\
\hline \multirow{6}{*}{ Demand uncertainty } & $-1.708 * *$ & $-1.448 * *$ & $-1.637 * *$ \\
\hline & $(0.671)$ & $(0.682)$ & $(0.814)$ \\
\hline & 0.464 & 0.314 & $1.221 *$ \\
\hline & (0.696) & $(0.672)$ & $(0.693)$ \\
\hline & -0.789 & -0.716 & $-2.313 * *$ \\
\hline & $(0.913)$ & $(0.889)$ & $(1.078)$ \\
\hline \multirow[t]{2}{*}{$\rho$} & $1.078^{* *}$ & $1.177 * *$ & $1.647 * * *$ \\
\hline & $(0.511)$ & $(0.468)$ & $(0.452)$ \\
\hline Log-likelihood & -112.3 & -139.8 & -179.8 \\
\hline chi2 & 21.75 & 20.59 & 21.01 \\
\hline Prob(chi2) & 0.0404 & 0.0567 & 0.0502 \\
\hline Observations & 294 & 294 & 294 \\
\hline
\end{tabular}

Note: All regressions include time dummies to control for year-specific effects and firm individual effects. Standard errors in parentheses and $* * *$ indicate significant at $1 \%, * *$ indicate significant at $5 \%$ and $*$ indicate significant at $10 \%$. 


\begin{tabular}{|c|c|c|c|}
\hline & \multicolumn{2}{|c|}{ Innovation: } \\
\hline & & Process & Product \\
\hline \multirow{2}{*}{\multicolumn{2}{|c|}{ Size }} & $0.298 * * *$ & 0.0728 \\
\hline & & $\begin{array}{l}(0.0503) \\
1.056 * * *\end{array}$ & 0.188 \\
\hline \multicolumn{2}{|l|}{ R\&D effort } & $(0.259)$ & $(0.153)$ \\
\hline \multirow[t]{2}{*}{ Group } & & $0.293 *$ & $0.446 * * *$ \\
\hline & & $(0.172)$ & $(0.164)$ \\
\hline \multicolumn{4}{|l|}{ Barriers: } \\
\hline Cost & & $\begin{array}{c}0.317 \\
(0.344)\end{array}$ & $\begin{array}{c}-0.0827 \\
(0.297)\end{array}$ \\
\hline Knowledge & & $\begin{array}{l}-1.148 \\
(0.710)\end{array}$ & $\begin{array}{l}-0.442 \\
(0.803)\end{array}$ \\
\hline \multicolumn{4}{|l|}{ Market: } \\
\hline & & $\begin{array}{c}-0.981 * * * \\
(0.280)\end{array}$ & $\begin{array}{c}-0.647 * * \\
(0.257)\end{array}$ \\
\hline & Demand uncertainty & $\begin{array}{l}0.0930 \\
(0.284)\end{array}$ & $\begin{array}{c}0.834 * * * \\
(0.250)\end{array}$ \\
\hline \multirow[t]{2}{*}{ Constant } & & $\begin{array}{c}-1.691 * * * \\
(0.328)\end{array}$ & $\begin{array}{c}-1.259 * * * \\
(0.315)\end{array}$ \\
\hline & & \multicolumn{2}{|c|}{$\begin{array}{c}0.236^{* *} \\
(0.0964)\end{array}$} \\
\hline
\end{tabular}

Note: Regression include time dummies to control for year-specific effects. Standard errors in parentheses and $* * *$ indicate significant at $1 \%$, ** indicate significant at $5 \%$ and $*$ indicate significant at $10 \%$. In the bivariate probit (assuming normality of the error terms) $\rho$ is a correlation parameter that provides information about the covariation of the error terms. 